\title{
Record of environmental changes and fluvial phases in the Late Holocene within the area of Podhale (the Carpathians, southern Poland): studies in the Falsztyński valley
}

\author{
Witold Paweł ALEXANDROWICZ1, * \\ 1 AGH University of Science and Technology, Faculty of Geology, Geophysics and Environment Protection, Chair of Gen- \\ eral Geology and Geotourism, al. A. Mickiewicza 30, 30-059 Kraków, Poland
}

Alexandrowicz, W.P., 2019. Record of environmental changes and fluvial phases in the Late Holocene within the area of Podhale (the Carpathians, southern Poland). Studies in the Falsztyński valley. Geological Quarterly, 63 (4): 629-642, doi: 10.7306/gq.1466

The Falsztyński valley, in the eastern part of Podhale, Poland includes a low terrace spanning the stream channel, the structure of which has been studied in nine profiles. Five gravel levels and five mud levels with plant and abundant mollusc remains are described, temporally constrained by ten radiocarbon dates. The terrace deposits represent the terminal part of the Atlantic Phase and all of the Late Holocene. The mollusc analysis helped identify phases of environmental change, notably one in the Middle Ages connected with intensive settlement activities in the area of Podhale. These include deforestation, affecting mollusc communities with replacement of forest assemblages by open-country species. The gravel levels records increased fluvial activity periods correlated with humid climate phases. It is possible to distinguish five such periods corresponding to the transition of the Atlantic and Subboreal phases, the middle part of the Subboreal Phase, the transition of the Subboreal and Subatlantic phases, the younger part of the Subatlantic Phase, and the last 200 years. These correspond to the periods of increased fluvial activity in the valleys of other Carpathian rivers.

Key words: environmental changes, molluscs, flood phases, Late Holocene, Podhale Basin, Southern Poland.

\section{INTRODUCTION}

The Holocene represents an interglacial phase that followed the recession of continental glaciers from Europe some 10,000 years ago. It is a phase of relatively warm climate favouring the expansion of forest communities, initially coniferous, later mixed and deciduous, into the area of Central Europe. It is also the interval of the development of human economy and the progression of anthropogenic pressure associated with it. Human activities left their mark in various parts of the area and with different intensities. In general, the mountain areas provided more difficult conditions for colonisation and economic activities than the lowland and upland parts. Therefore, human impact in the mountains appears significantly later, often even during the most recent centuries. During the Holocene, the warmer climatic phases were interspaced with cooler phases, and more humid periods with drier ones. Those fluctuations significantly affected the course and intensity of geological processes. The cooler and more humid periods were marked by phases of glacier invasions in the Alps (e.g., Patzelt, 1977; Bortenschlager, 1982; Nussbaumer et al., 2011) and in Scandi-

\footnotetext{
*E-mail: wpalex@geol.agh.edu.pl
}

Received: October 16, 2018; accepted: February 7, 2019; first published online: May 15, 2019 navia (Karlén, 1988; Nesje, 2009), by elevated water levels in both in mountain lakes (e.g., Magny, 1993, 2004; Holzhauser et al., 2005) and lowland lakes (e.g., Ralska-Jasiewiczowa and Starkel, 1988; Wojciechowski, 1999; Alexandrowicz, 2013a), as well as by phases of intensification of mass movements (e.g., Alexandrowicz, 1997a, 2013b; Starkel, 1997; Margielewski, 1998, 2006; Dapples et al., 2002). The record of humid climatic phases is very evident in the profiles of alluvial deposits, principally in the form of erosive surfaces and gravel levels. In the Polish Carpathians, studies of these deposits and processes have a long tradition. Numerous recorded profiles have permitted the distinction of a number of periods with intensified river activity and their correlation with phases of climate humidity (e.g., Starkel et al., 2006, 2015; Gębica, 2011, 2013a, b). However, the great majority of these analyses are concentrated in the valleys of major rivers, and the valleys of smaller rivers and streams have not been studied so closely in this respect.

The finer river deposits (sands and muds) often contain the shells of subfossil molluscs. Within the gravels, shells occur much more rarely, because they were rapidly crushed and removed from the sediment. The presence of calcium carbonate which limits the possibility of chemical dissolution of the shells, chiefly by organic acids, is also essential (Alexandrowicz and Alexandrowicz, 2011).

The present study is devoted to two major issues. Firstly, the sequence of faunal assemblages provides a basis for reconstructing palaeoenvironmental change within Falsztyński 


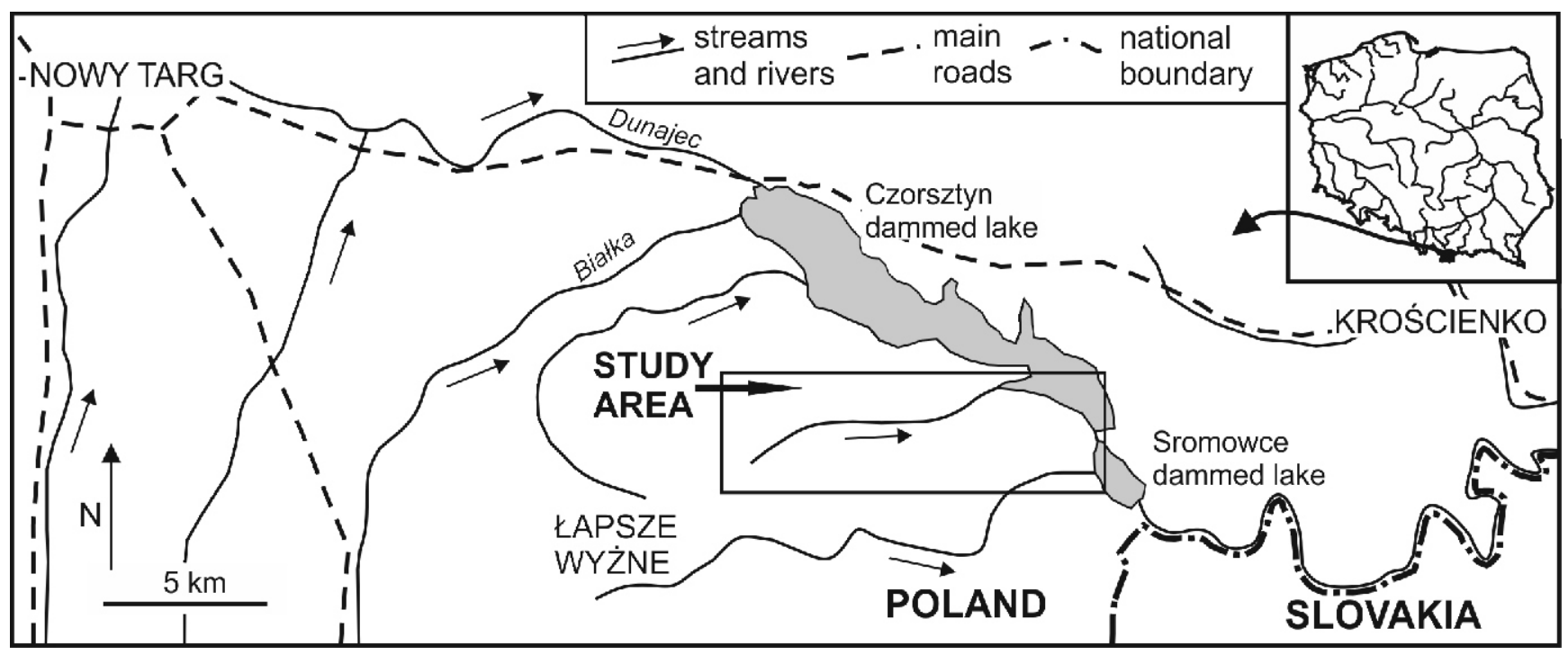

Fig. 1. Location of the study area

Stream valley, particularly as regards the effect of climate changes and human impact. Secondly, climatic phases are distinguished, particularly the periods of increased humidity showing as increased intensities of fluvial processes, and correlated with records of comparable events in other river valleys, including analyses of lake sediments affected by landslides and of changes of glacier ranges within Europe.

\section{STUDY AREA}

The study area is situated within the Podhale Basin. It is an intermontane depression surrounded by the elevated massifs of the Beskidy Mountains to the north, and of the Tatra Mountains to the south. The basin is filled with Paleogene flysch, gently folded in the Lower Miocene. In the northern part of the area there is a belt of strongly deformed Jurassic and Cretaceous limestones forming the Pieniny Klippen Belt (Birkenmajer, 1977, 1986a; Golonka et al., 2018). The Falsztyński Stream cuts through the formations of the Pieniny Klippen Belt via the tectonic zone situated in its substrate (Birkenmajer, 1986b). The valley studied is situated in the eastern part of the Podhale region (Fig. 1). The Falsztyński Stream is $\sim 2 \mathrm{~km}$ long. Its sources are situated at $\sim 650 \mathrm{~m}$ a.s.I. in the Branisko massif. Originally, it was a right-bank tributary of the Dunajec River. However, after a dam was built at Niedzica, it now empties into Lake Czorsztyn (Figs. 1 and 2). The stream channel is limited by a terrace up to 2 metres high, but usually not exceeding $1.5 \mathrm{~m}$. The valley itself has a relatively wide, flat floodplain and only in its highest part assumes the appearance of a V-shaped valley. Near the end of the 20th century, the slopes and floor of the valley were deforested and taken over by cultivated fields, grasslands, and pastures. In the last ten years or so, farming activities have been much limited, and this has resulted in a marked expansion of forest within the valley.

\section{MATERIAL AND METHODS}

Field studies over several years established profiles within the low terrace stretching along the bed of the Falsztyński Stream. Initially, the analyses covered five profiles, with preliminary results included in a monograph on the Quaternary molluscs of the Podhale region (Alexandrowicz, 1997b). Studies conducted subsequently included a detailed analysis of the structure of the lower terrace of the Falsztyński Stream, obtaining further mollusc remains (in four more profiles), and material for radiocarbon dating (10 dates). In all, the studies were based on nine profiles (including one situated in the lowest part of the valley, now flooded by the waters of the Czorsztyn Lake; Fig. 2). The mollusc samples were collected in particular profiles in correspondence with lithology. Their mass was $\sim 2-3 \mathrm{~kg}$. In total, with 100 samples were collected. Gravel samples were devoid of molluscan shells or contained at most crushed and unidentifiable shell fragments. Within the muds, the molluscs were abundant and well-preserved. Laboratory procedures included washing the material through sieves with a 5.0 mesh size. After drying, the mollusc shells and their fragments were removed. Identification was made with the use of published guides (Kerney et al., 1983; Wiktor, 2004; Welter-Schultes, 2012; Horsák et al., 2013) and reference collections. In each sample, the numbers of particular taxa were determined. Individual species were allocated to ecological groups in accordance with the scheme proposed by Ložek (1964), Alexandrowicz and Alexandrowicz (2011) and Juřičková et al. (2014a). The percentage shares of species and ecological groups provided the basis for the construction of mollusc spectra (Ložek, 1964; Alexandrowicz and Alexandrowicz, 2011). The use of a dendrogram of similarities involved the PAST statistical package (Hammer et al., 2001) combined with the use of the formula developed by Morisita (1959), enabling the identification of three principal types of fauna. The stratigraphic position of the deposits was determined using the mollusc analyses and 


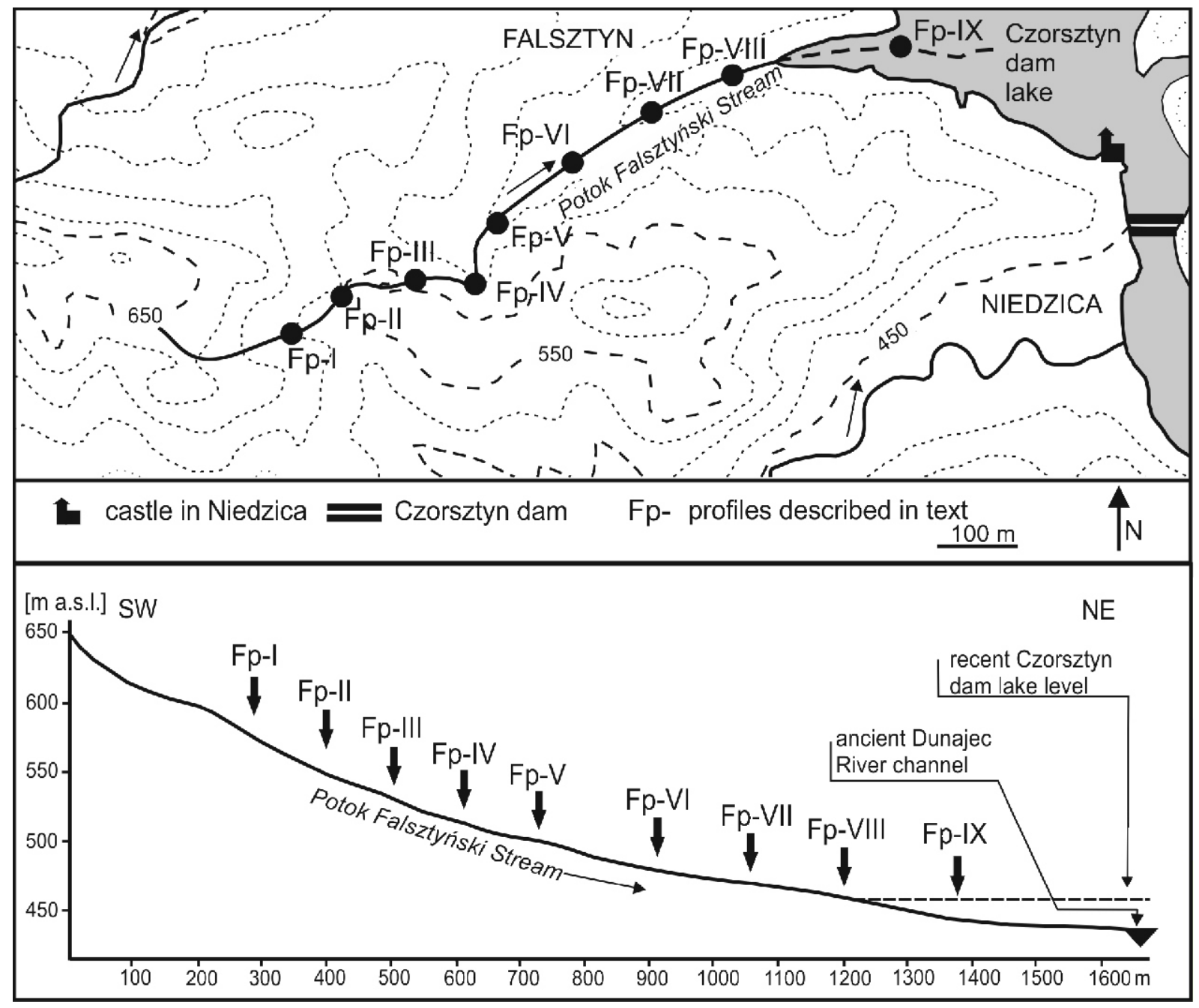

Fig. 2. Location of profiles of alluvial deposits in the Falsztyński valley and a longitudinal section of the valley

through radiocarbon age dating of plant remains in the deposits. The results of age determinations were calibrated using the OxCal software package (Bronk Ramsey, 2017). The radiometric analyses (conventional dates) were conducted in the Absolute Dating Methods Centre, Institute of Physics, Silesian University of Technology in Gliwice (laboratory code Gd).

\section{RESULTS}

\section{LITHOLOGY}

The geological structure of the deposits shaping the low terrace along the Falsztyński valley is relatively uniform. The underlying rocks are exposed on its floor and comprise thinly layered strongly calcareous sandstones and grey calcareous shales. The top of the bedrock is up to ten centimetres above the present stream level. The overlying alluvial deposits are from $0.9 \mathrm{~m}$ (profile Fp-I) to $2.40 \mathrm{~m}$ (profile Fp-VI) thick (Figs. 3 and 4). They are of two facies. The first includes fine- and medium-grained gravels made of sandstone cobbles in a sparse sandy matrix. The cobbles are only slightly rounded and usually discoidal. Their long axes are $5-15 \mathrm{~cm}$ long, most often $6-10 \mathrm{~cm}$. Sporadically, larger clasts (up to $25 \mathrm{~cm}$ ) occur. There are few sedimentary structures except for traces of imbrication.
Within the terrace, gravels form 3-5 beds from 0.1 to $0.45 \mathrm{~m}$ thick in the profiles (Figs. 3 and 4). They are interbedded with strongly calcareous dark grey muds that locally include thin layers or lenses of fine-grained sands. These muds also include many plant remains, locally in larger accumulations. The plant detritus is mostly comminuted, although there are also some fragments of branches. This material, collected from some of the profiles, provided the basis for radiocarbon dating (Figs. 3 and 4). In the muds, numerous and well-preserved mollusc shells were found. The number of muddy layers in particular profiles varied from three to five and their thickness ranges from 0.1 to $0.5 \mathrm{~m}$ (Figs. 3 and 4). The top of the terrace is made of a thin layer of recent soil.

\section{MOLLUSC FAUNA}

The mollusc fauna identified in the muds was rich and abundant. In 54 samples, there were 53 taxa of terrestrial snails, 2 of water snails, and 2 species of bivalves, as well as calcareous plates of slugs (Limacidae). The numbers of taxa in particular samples fluctuated from 9 to 44 , and the number of specimens from 100 to 593 . Nearly 13,000 specimens were identified in total. The material also contained unidentifiable broken fragments of shells (more than 1200; Table 1). 
$\operatorname{Pr} \quad S p$

Malacofauna

C-14
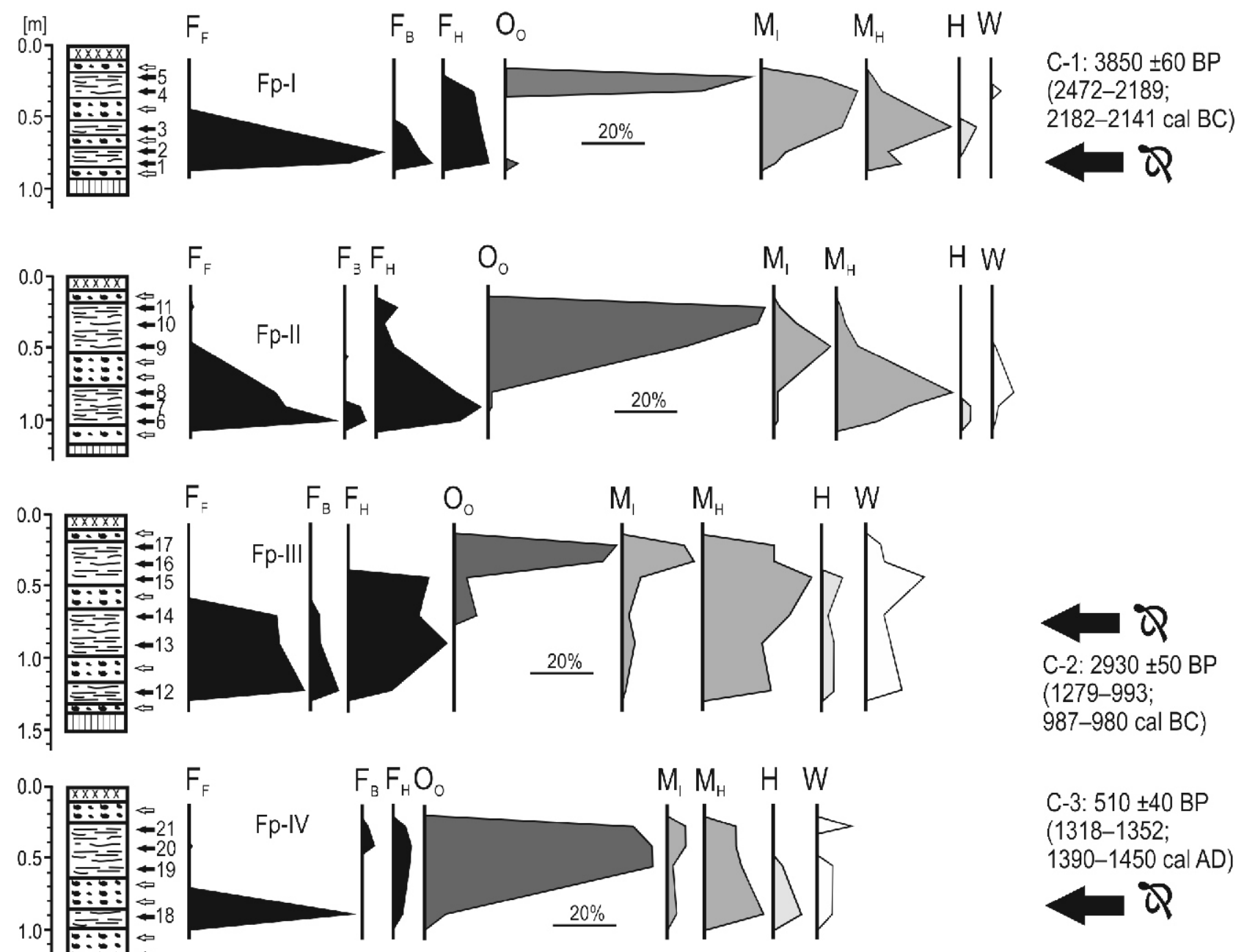

C- $3: 510 \pm 40$ BP

(1318-1352;

1390-1450 cal AD)

Q

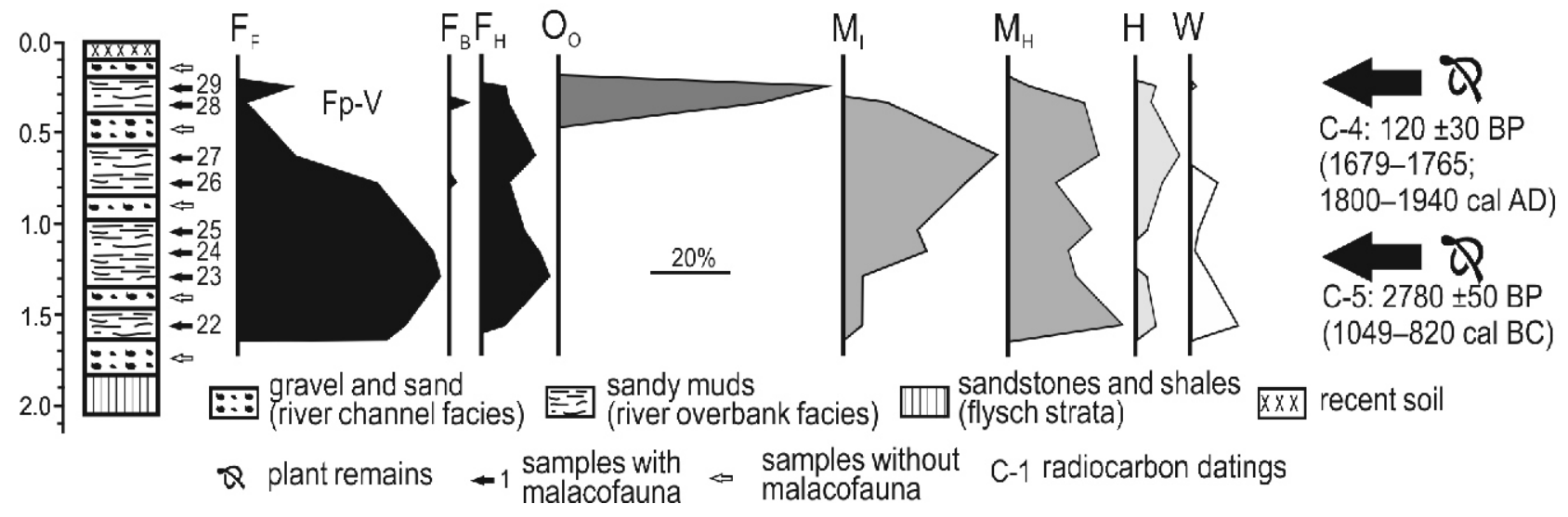

Fig. 3. Lithology and mollusc fauna of alluvial deposits of the Falsztyński valley (profiles Fp-I-Fp-V)

$\mathrm{Pr}$ - profiles; Sp - samples; ecological groups of molluscs (according to Ložek, 1964; Alexandrowicz and Alexandrowicz, 2011; Juřičková et al., 2014a); $F_{F}$ - shade-loving, forest species, $F_{B}$ - shade-loving species living in light forests and bushy areas, $F_{H}$ - shade-loving species of humid habitats, $\mathrm{O}_{\mathrm{O}}$ - open-country species, $\mathrm{M}_{1}$ - mesophilous species of moderately wet habitats, $\mathrm{M}_{\mathrm{H}}$ - mesophilous species of wet habitats, $\mathrm{H}$ - hygrophilous species, $\mathrm{W}$ - water species 
$\operatorname{Pr} \quad S p$
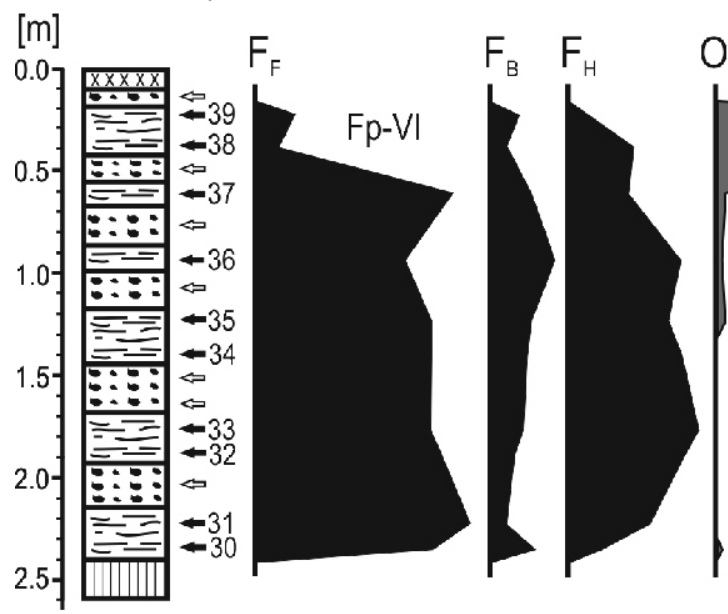

Malacofauna
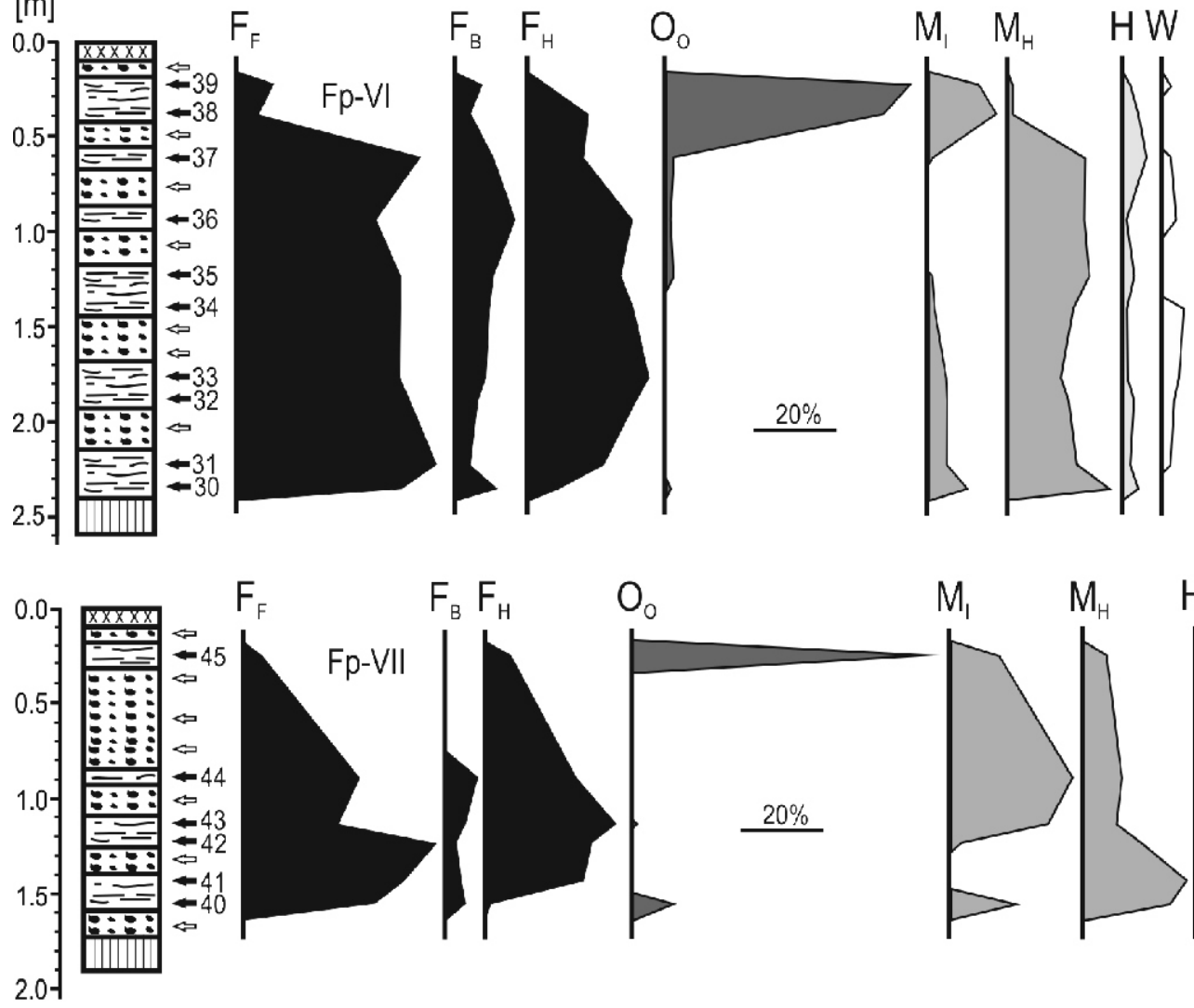

$\mathrm{F}_{\mathrm{B}} \mathrm{F}_{\mathrm{H}}$

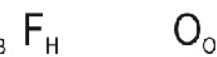

$20 \%$
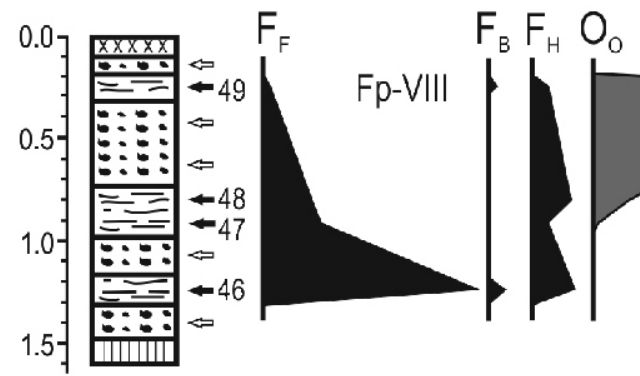

$\mathrm{O}_{0}$

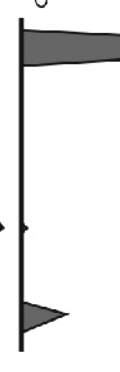

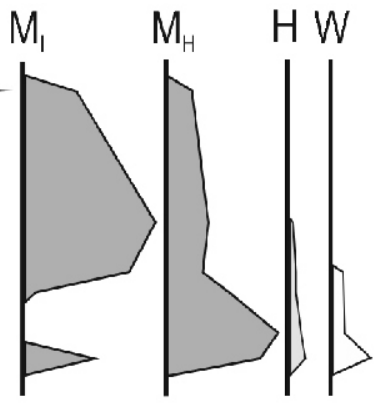

C-14

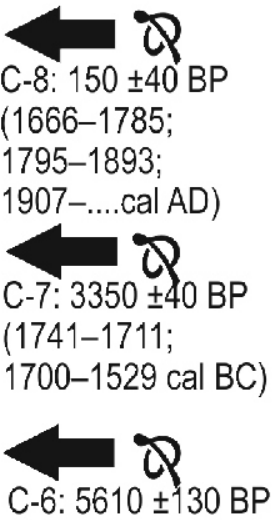

C- $6: 5610 \pm 130 \mathrm{BP}$
$(4712-4257 \mathrm{cal} \mathrm{BC})$

C-9: $4400 \pm 80 \mathrm{BP}$ (3339-3206; 3196-2897 cal BC)

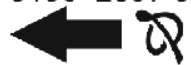

C- $10: 480 \pm 40 \mathrm{BP}$ (1394-1476 cal AD) Q

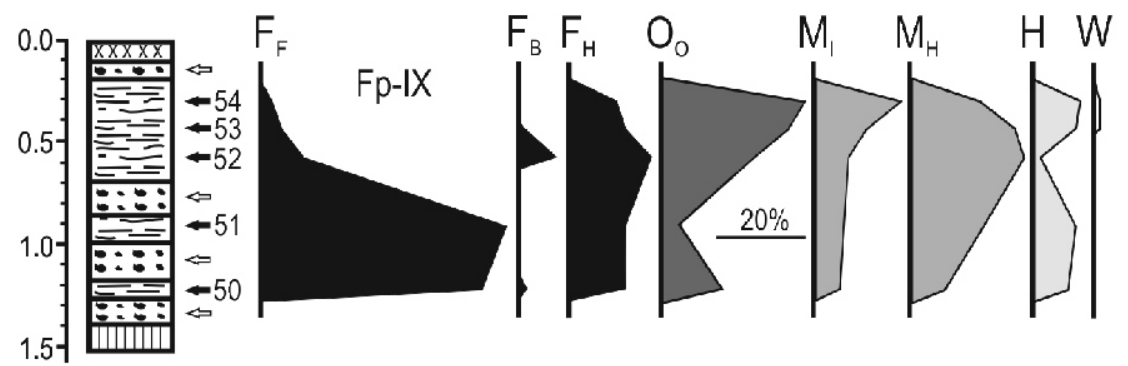

Fig. 4. Lithology and mollusc fauna of alluvial deposits of the Falsztyński valley (profiles Fp-I-Fp-V) 
List of species recognized in profiles of alluvial deposits in the Falsztyński valley

\begin{tabular}{|c|c|c|c|c|c|c|c|c|c|c|}
\hline$E$ & Taxon & Fp-I & Fp-II & Fp-III & Fp-IV & $\mathrm{Fp}-\mathrm{V}$ & Fp-VI & Fp-VII & Fp-VIII & Fp-IX \\
\hline \multirow{21}{*}{$F_{F}$} & Acicula parcelineata (Cless.) & 7 & 7 & 1 & - & 8 & 28 & 13 & 2 & - \\
\hline & Platylla polita (Hartm.) & 16 & 10 & 49 & 1 & 18 & 48 & 32 & 15 & 9 \\
\hline & Argna bielzi (Rossm.) & 4 & 21 & 6 & - & - & 16 & - & - & - \\
\hline & Acanthinula aculeata (Müll.) & 5 & 3 & 2 & - & 7 & 31 & 4 & - & - \\
\hline & Vertigo pusilla Müll. & 6 & - & - & - & 4 & 12 & 6 & - & - \\
\hline & Ena montana (Drap.) & 2 & 14 & 13 & 4 & 8 & 35 & 11 & 3 & 9 \\
\hline & Cochlodina laminata (Mont.) & 1 & 2 & 1 & 3 & - & 3 & 4 & - & - \\
\hline & Cochlodina orthostoma (Menke) & - & 2 & - & - & - & 3 & 3 & - & 2 \\
\hline & Ruthenica filograna (Rossm.) & 11 & 7 & 19 & 10 & 43 & 31 & 23 & - & - \\
\hline & Macrogastra plicatula (Drap.) & - & - & 1 & - & 8 & 4 & 4 & - & - \\
\hline & Discus ruderatus (Hart.) & 9 & 6 & 5 & & 23 & 40 & 25 & 10 & 15 \\
\hline & Discus perspectivus (von Mühl.) & 24 & 17 & 10 & & 31 & 28 & 30 & 6 & 13 \\
\hline & Vitrea diaphana (Stud.) & 72 & 90 & 59 & 12 & 58 & 286 & 107 & 37 & 30 \\
\hline & Vitrea transsylvanica (Cless.) & 26 & 10 & 13 & 7 & 51 & 56 & 15 & 19 & 7 \\
\hline & Vitrea subrimata (Reinh.) & 16 & 10 & 18 & - & - & 71 & - & 1 & 3 \\
\hline & Mediterranea depressa (Sterki) & - & 7 & - & - & - & 44 & 18 & - & - \\
\hline & Aegopinella pura (Ald.) & 97 & 88 & 62 & 11 & 54 & 238 & 101 & 36 & 18 \\
\hline & Eucobresia nivalis (Dum.\& Mort.) & 5 & 20 & 11 & 2 & 29 & 85 & 49 & - & 9 \\
\hline & Petasina unidentata (Drap.) & 17 & 24 & 6 & - & 2 & 56 & 13 & 1 & 5 \\
\hline & Faustina faustina (Rossm.) & 2 & 26 & 11 & - & 11 & 36 & 29 & - & - \\
\hline & Isognomostoma isognomostomos (Schr.) & 15 & 23 & 38 & 5 & 25 & 112 & 30 & 1 & 15 \\
\hline \multirow{6}{*}{$\mathrm{F}_{\mathrm{B}}$} & Vertigo ronnebyensis (West.) & 1 & 1 & - & - & - & 7 & 2 & - & - \\
\hline & Discus rotundatus (Müll.) & 11 & 8 & - & - & - & 46 & - & - & - \\
\hline & Aegopinella minor (Stabile) & 29 & 18 & 18 & - & 3 & 108 & 37 & 6 & - \\
\hline & Semilimax kotulae (Drap.) & 6 & 4 & 5 & - & 2 & 18 & 15 & 2 & - \\
\hline & Fruticicola fruticum (Müll.) & 9 & 13 & 15 & - & - & 23 & 8 & 2 & - \\
\hline & Monachoides incarnatus (Müll.) & 10 & 3 & 7 & 6 & 7 & 41 & 2 & - & 15 \\
\hline \multirow{5}{*}{$\mathrm{F}_{\mathrm{H}}$} & Vestia turgida (Rossm.) & - & 4 & 5 & - & - & 16 & 3 & - & \\
\hline & Vestia gulo (Bielz) & - & 11 & 4 & 2 & 2 & 6 & - & - & 23 \\
\hline & Vitrea crystallina (Müll.) & 75 & 226 & 169 & 1 & 106 & 596 & 282 & 24 & 54 \\
\hline & Monachoides vicinus (Rossm.) & 202 & 57 & 77 & 17 & 17 & 75 & 19 & 17 & 40 \\
\hline & Urticicola umbrosus (Pfeiffer) & 1 & - & - & - & - & 12 & - & 3 & - \\
\hline \multirow{4}{*}{$\mathrm{O}_{\mathrm{O}}$} & Vallonia costata (Müll.) & 106 & 172 & 186 & 105 & 97 & 37 & 53 & 40 & 90 \\
\hline & Vallonia pulchella (Müll.) & 264 & 346 & 128 & 78 & 152 & 129 & 51 & 33 & 76 \\
\hline & Pupilla muscorum (L.) & 57 & 52 & 65 & 36 & 22 & 12 & 13 & 13 & - \\
\hline & Vertigo pygmaea (Drap.) & 22 & 26 & 6 & 17 & 8 & 4 & 6 & 9 & - \\
\hline \multirow{8}{*}{$M_{1}$} & Cochlicopa Iubrica (Müll.) & 59 & 30 & 49 & 5 & 70 & 100 & 47 & 34 & 81 \\
\hline & Clausilia dubia Drap. & - & 2 & 3 & - & - & 4 & 3 & 1 & 3 \\
\hline & Punctum pygmaeum (Drap.) & 46 & 28 & 52 & - & 77 & 9 & 52 & 39 & 24 \\
\hline & Vitrea contracta (West.) & 4 & 5 & 10 & 12 & - & 2 & - & 8 & 20 \\
\hline & Euconulus fulvus (Müll.) & 47 & 9 & 14 & - & 4 & 14 & 45 & 40 & - \\
\hline & Perpolita hammonis (Ström) & 48 & 14 & 35 & - & 10 & 24 & 15 & 57 & 1 \\
\hline & Vitrina pellucida (Müll.) & 4 & 1 & 1 & - & - & - & - & - & - \\
\hline & Limacidae & 12 & 6 & 21 & 3 & 11 & 3 & - & 7 & 11 \\
\hline \multirow{7}{*}{$\mathrm{M}_{\mathrm{H}}$} & Carychium tridentatum (Risso) & 53 & 129 & 75 & 9 & 101 & 306 & 174 & 34 & 55 \\
\hline & Succinella oblonga (Drap.) & 3 & - & 63 & 6 & - & 13 & - & - & - \\
\hline & Vertigo substriata (Jeff.) & 4 & 3 & - & - & 22 & 41 & 34 & - & - \\
\hline & Vertigo angustior Jeff. & - & 10 & 67 & - & - & - & - & - & - \\
\hline & Trochulus villosulus (Rossm.) & 1 & 5 & 9 & - & - & 15 & 4 & - & - \\
\hline & Perforatella bidentata (Gmel.) & 27 & 37 & 119 & 16 & 28 & 48 & 23 & 2 & 32 \\
\hline & Arianta arbustorum (L.) & 39 & 35 & 101 & 25 & 47 & 94 & 15 & 75 & 67 \\
\hline \multirow{3}{*}{$\mathrm{H}$} & Carychium minimum Müll. & 1 & 18 & 1 & 8 & 36 & 54 & 26 & 8 & 40 \\
\hline & Succinea putris (L.) & 11 & 5 & 42 & 4 & 28 & 19 & 11 & 5 & 23 \\
\hline & Vertigo geyeri Lindh. & - & - & - & - & - & 8 & 3 & - & - \\
\hline \multirow{4}{*}{ W } & Galba truncatula (Müll.) & 8 & 19 & 89 & 5 & 24 & 49 & 25 & 6 & - \\
\hline & Anisus leucostoma Standb. & - & 3 & 48 & 22 & - & - & - & - & 4 \\
\hline & Pisidium casertanum (Poli) & - & - & 18 & - & - & 9 & - & - & - \\
\hline & Pisidium personatum Malm & 5 & 5 & 6 & - & 17 & 35 & 20 & - & - \\
\hline \multicolumn{2}{|c|}{ Total species } & 48 & 52 & 50 & 28 & 40 & 63 & 50 & 34 & 31 \\
\hline \multicolumn{2}{|c|}{ Total individuals } & 1274 & 1697 & 1840 & 431 & 1275 & 3293 & 1515 & 597 & 802 \\
\hline \multicolumn{2}{|c|}{ Indeterminate shells fragments } & 157 & 201 & 197 & 63 & 112 & 233 & 122 & 88 & 75 \\
\hline
\end{tabular}


The taxa in the material analysed represented all principal ecological groups. The most numerous were shade-loving species (32 taxa). The forest species (ecological group $F_{F}$ ) include both species preferring the high proportion of coniferous trees (Discus ruderatus), as well as snails typical of mixed and deciduous forests (Discus perspectivus, Ruthenica filograna, Aegopinella pura). The presence of taxa which prefer a relatively humid substrate (Vitrea diaphana) is a characteristic feature (Table 1). Slightly less numerous are taxa typical of sparse forests and shrubs (ecological group $\mathrm{F}_{\mathrm{B}}$ ). The presence of Vertigo ronnebyensis and Semilimax kotulae warrants particular attention. The first was recorded in several Late Glacial and Early Holocene localities within the Polish part of the Carpathians (Alexandrowicz, 1997b, 2004, 2013c; Alexandrowicz et al. 2014, 2016). It went extinct in the area, probably during the Middle Holocene. Semilimax kotulae is often found in the Carpathians, and it is common in Early Holocene deposits. Nowadays, it can be regarded as a glacial relict (Alexandrowicz, 1997b, 2004, 2013c; Wiktor, 2004; Alexandrowicz et al., 2014 2016; Juřičková et al., 2014b; Horáčková et al., 2015; Table 1). The third group of shade-loving snails consists of species characteristic of humid and very humid habitats (ecological group $F_{H}$ ): Vitrea crystallina and Monachoides vicinus (Table 1). The shade-loving species are most numerous in the lower parts of the profiles, and rare in their tops (Figs. 3, 4 and Table 1). Four species are forms typical of open, forest-free habitats (ecological group $\mathrm{O}_{\mathrm{O}}$ ). Two of the species (Vallonia pulchella and Vallonia costata) appear in very great numbers high in the profiles where they are predominant (Figs. 3, 4 and Table 1). Species of wide ecological tolerance (mesophilous) occur in all samples, but usually only as a supplementary component of the fauna. Taxa requiring moderate levels of moisture (ecological group $M_{1}$ ) as well as taxa preferring humid substrates (ecological group $\mathrm{M}_{\mathrm{H}}$ ) are present here. The first group includes common and widely distributed snails such as Punctum pygmaeum, Perpolita hammonis, and Euconulus fulvus. The characteristic component of the second group comprises two species often found in overshadowed and very humid habitats on the floodplains of rivers and streams (Perforatella bidentata and Arianta arbustorum; Figs. 3, 4 and Table 1). Hygrophilous species (ecological group $\mathrm{H}$ ) occur only rarely. Of note is the presence of the cold-loving tundra taxon Vertigo geyeri. This snail is known to occur in the Pleistocene, Late Glacial, and Early Holocene successions of the Podhale Basin (Alexandrowicz, 1997b, 2004, 2013c, 2015; Alexandrowicz et al., 2014). It has recently been reported from this area as a glacial relict (Pokryszko 1990, 2003; Limondin-Lozouet, 1992; Krolopp and Sumegi 1993; Schénkova et al., 2012; Figs. 3, 4 and Table 1). Aquatic molluscs (ecological group W) are represented by only four taxa, and they play only a secondary role in the assemblage (Figs. 3, 4 and Table 1).

\section{FAUNAL ASSEMBLAGES}

The use of a similarity dendrogram permitted the recognition of three types of mollusc assemblages (Fig. 5). The first type includes major proportions of shade-loving species (often exceeding $60 \%$ of the assemblage; S-L, Fig. 5). Faunas of this nature are present in the lower intervals of all profiles analysed Mesophilous snails supplement the assemblages and the representatives of other ecological groups constitute only a small admixture. This fauna characterises a strongly overshadowed environment of mixed and coniferous forests growing on a relatively humid substrate. Rich and species-diverse assemblages with a relatively large proportion of shade-loving taxa have been described from Quaternary deposits of the Podhale Basin
(Alexandrowicz, 1997b, 2001, 2004, 2013c, 2015, 2017; Alexandrowicz and Rybska, 2013; Alexandrowicz et al., 2014, 2016). Their occurrence is usually associated with a warm and humid climate, here corresponding to the Middle Holocene climatic optimum (Atlantic Phase). It is most probable that, after that phase, during the Subboreal Phase, the diversity of the shade-loving component in the assemblages decreased as a result of adverse climatic changes. This is particularly clearly seen in a remarkable decrease in the frequency of species with high habitat and thermal requirements. This tendency is also clearly seen in the Falsztyński valley profies. While shells of Discus perspectivus, Ruthenica filograna and several other species are present in the lower parts of the profiles, they disappear upwards being replaced by forms with lower ecological requirements. These observations indicate that the deposition of the terrace deposits in the Falsztyński valley started in the final part of the Atlantic Phase and persisted through the entire Late Holocene (Subboreal and Atlantic phases). Such conclusions are supported by the results of radiocarbon dating (dates $\mathrm{C}-1$, C-2, C-5, C-6, C-7 and C-9; Figs. 3, 4 and Table 2). The second type of fauna (O-C, Fig. 5) is characterized by a predominance of open-country snails (Vallonia pulchella, Vallonia costata) whose proportion in the assemblages usually exceeds $60 \%$. It is also characterized by a poor species composition, and in particular, by a very low proportion of shade-loving taxa. This assemblage indicates the existence of open-country, grassland habitats, and a relatively dry substrate. Faunas of similar type were reported from the area of the Podhale Basin at a number calcareous tufa and alluvial deposit localities (Alexandrowicz, 1997b, 2013c; Alexandrowicz and Rybska, 2013; Alexandrowicz et al., 2014) that accumulated during the last several centuries. The top parts of the profiles in the Falsztyński valley may be associated with the same period. The links between the deposits and the historical period are also constrained by the radiocarbon dates (dates C-3, C-4, C-8 and C-10; Figs. 3, 4 and Table 2). The emergence of the assemblages dominated by the species of open habitats and the rapid disappearance of shade-loving assemblages was undoubtedly associated with the anthropogenic deforestation of large areas of the Podhale region. The occurrence of a number of mesophilous species is characteristic of the last assemblage type (MI, Fig. 5). It was found only in a few samples. This assemblage can be regarded as a transitional type between those described above.

\section{DISCUSSION}

Within the terrace, the analysis of the gravel and mud successions, supported by mollusc assemblage analyses and age determinations, allowed the identification of five levels of gravel separated by mud deposits (Fig. 6). These levels can be correlated with periods of intensified fluvial activity seen flood phases. The presence of many mollusc shells in the muds allows reconstruction of the habitats existing between these phases.

\section{DEVELOPMENT OF THE FALSZTYŃSKI VALLEY DURING} THE LATE HOLOCENE

The chronologically oldest deposits are exposed in the profile Fp-IV, and they are represented by a mud unit with abundant fauna. These rest directly on bedrock (M-1, Figs. 6 and 7). The molluscs within that part of the profile comprise chiefly shade-loving species among which are some with high ecological requirements (particularly thermal; e.g., Discus perspectivus, Ruthenica filograna). The ecological structure of 


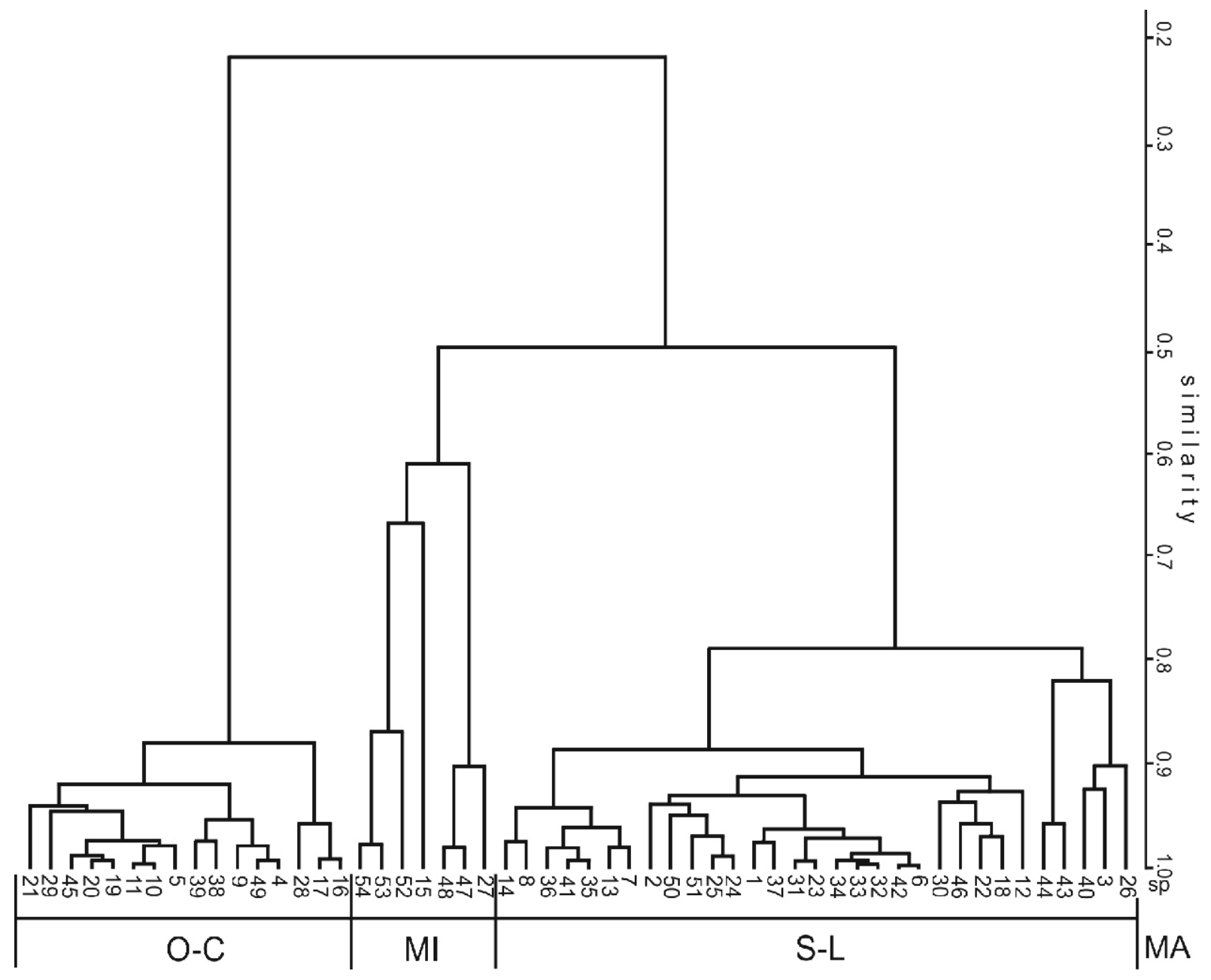

Fig. 5. Cluster analysis of mollusc faunas from the alluvial deposits of the Falsztyński valley

O-C, MI, S-L - types of mollusc fauna described in text, sp - samples

Table 2

Radiocarbon dates

\begin{tabular}{|c|c|c|c|c|}
\hline Date & Age (BP) & Lab. code & Age (cal BC/AD) & Material \\
\hline C-1 & $3850 \pm 60$ & Gd-12178 & $\begin{array}{c}2472-2189 \text { cal BC }(90.0 \%) \\
2182-2141 \text { cal BC }(5.4 \%)\end{array}$ & plant remains \\
\hline C-2 & $2930 \pm 50$ & Gd-5106 & $\begin{array}{c}1279-993 \text { cal BC }(95.0 \%) \\
987-980 \text { cal BC }(0.4 \%)\end{array}$ & plant remains \\
\hline C-3 & $510 \pm 40$ & Gd-10026 & $\begin{array}{l}1318-1352 \text { cal AD }(14.7 \%) \\
1390-1450 \text { cal AD }(80.7 \%)\end{array}$ & plant remains \\
\hline C-4 & $120 \pm 30$ & Gd-19046 & $\begin{array}{l}1679-1765 \text { cal AD }(32.6 \%) \\
1800-1940 \text { cal AD }(62.8 \%)\end{array}$ & plant remains \\
\hline$C-5$ & $2780 \pm 50$ & Gd-19185 & $1049-820$ cal BC $(95.4 \%)$ & plant remains \\
\hline C-6 & $5610 \pm 130$ & Gd-2316 & $\begin{array}{c}4784-4229 \text { cal BC }(94.6 \%) \\
4197-4173 \text { cal BC }(0.8 \%)\end{array}$ & plant remains \\
\hline $\mathrm{C}-7$ & $3350 \pm 40$ & Gd-17353 & $\begin{array}{l}1741-1711 \text { cal BC }(8.8 \%) \\
1700-1529 \text { cal BC }(86.6 \%)\end{array}$ & plant remains \\
\hline C-8 & $150 \pm 40$ & Gd-5754 & $\begin{array}{c}1666-1785 \text { cal AD }(45.7 \%) \\
1795-1893 \text { cal AD }(32.3 \%) \\
1907-\ldots . \text { cal AD }(17.4 \%)\end{array}$ & plant remains \\
\hline C-9 & $4400 \pm 80$ & Gd-8052 & $\begin{array}{l}3339-3206 \text { cal BC }(23.6 \%) \\
3196-2897 \text { cal BC }(71.8 \%)\end{array}$ & plant remains \\
\hline C-10 & $480 \pm 40$ & Gd-5269 & $\begin{array}{c}1327-1343 \text { cal AD }(2.6 \%) \\
1394-1476 \text { cal AD }(92.8 \%)\end{array}$ & plant remains \\
\hline
\end{tabular}




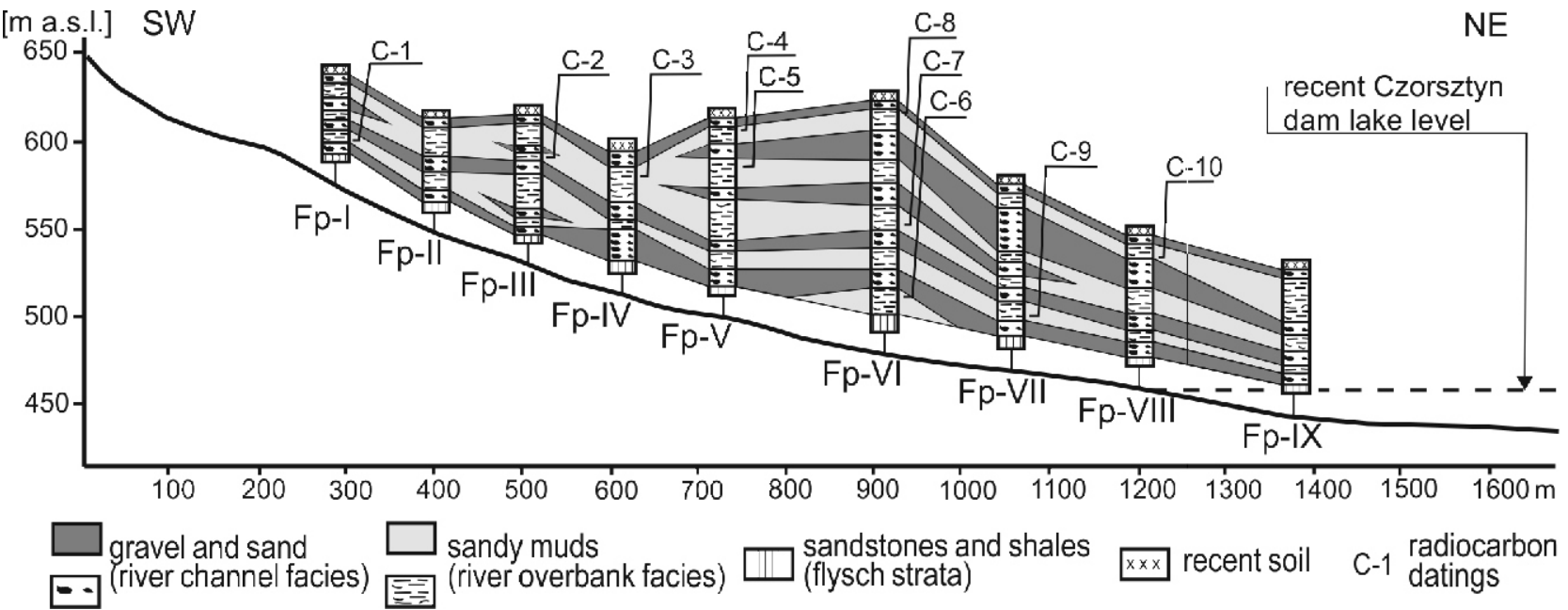

Fig. 6. Internal structure of the low Falsztyński terrace

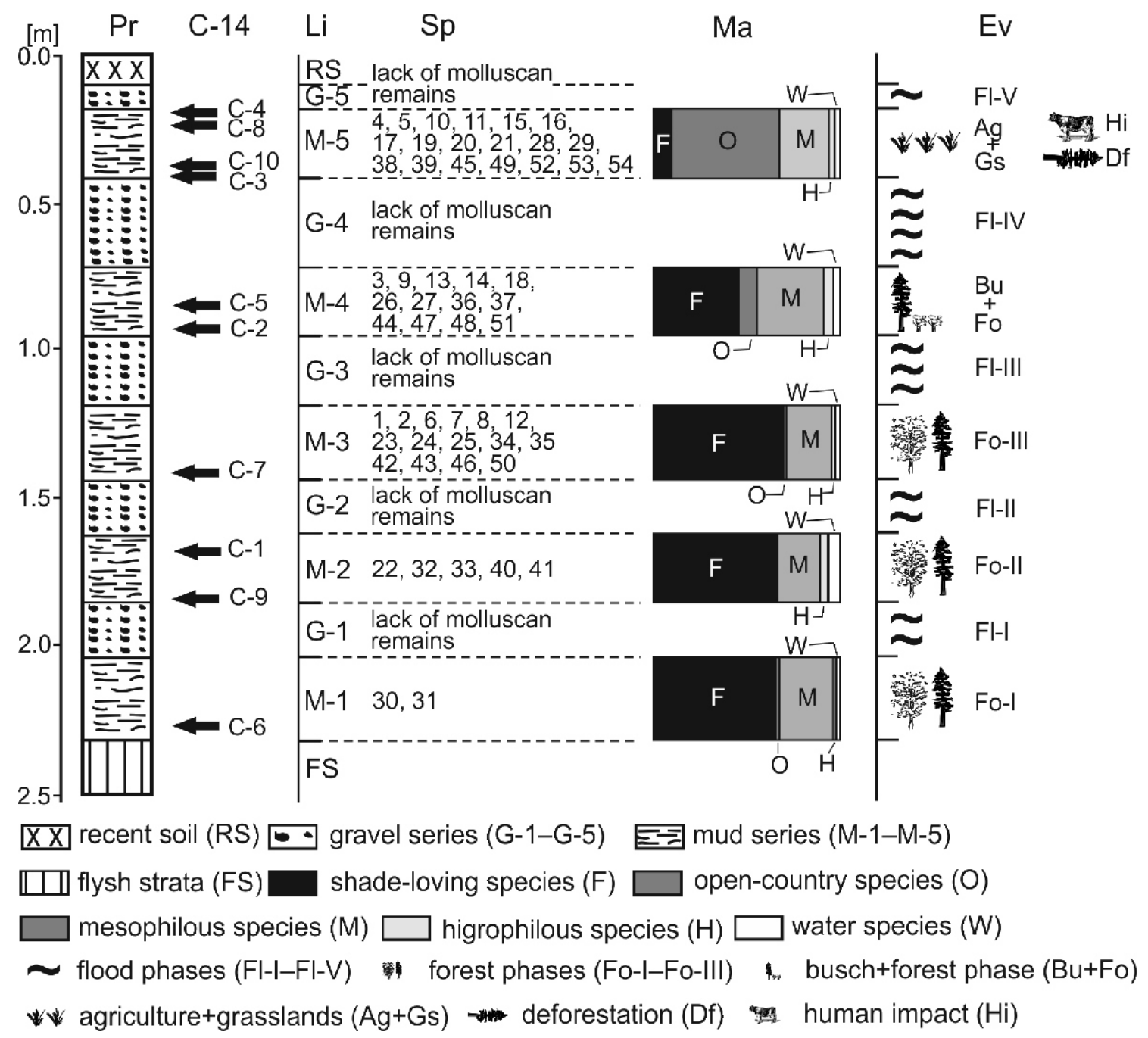

Fig. 7. Environmental changes in the Falsztyński valley during Late Holocene

$\mathrm{Pr}$ - synthetic profile, C-14 - radiocarbon dates, Li - lithology, Sp - samples, Ma - mollusc fauna, Ev - environment 
this fauna indicates a predominance of forest communities with major proportions of deciduous trees growing on a relatively humid substrate, persisting throughout this period (Fig. 7). The small proportion of species from the remaining ecological group indicates the low importance of other types of habitats. Radiocarbon dating of this layer yielded the following results: $5610 \pm 130$ BP (4784-4229 cal BC and 4197-4173 cal BC date C-6; Figs. 6, 7 and Table 2). This indicates that this part of the succession was deposited close to the end of the Atlantic Phase. The mollusc analyses lead to similar conclusions. In the Podhale Basin, the period of the Holocene Climatic Optimum was characteriedz by the development of deciduous and mixed forest communities. This is well-documented in the palynological profiles of the peatbogs in the western part of the Podhale Basin (Orawa Basin; pollen zones: Ulmus-Tilia-Quercus-Fraxinus and Corylus; Obidowicz, 1990; Rybniček and Rybničková, 2002) as well as in many mollusc profiles (Alexandrowicz, 1997b, 2001, 2004, 2013c, 2015, 2017; Alexandrowicz and Rybska, 2013; Alexandrowicz et al., 2014, 2016). In profile Fp-VI, these muds are overlain by the oldest gravel layer (G-1). In the remaining profiles, it rests directly on bedrock (Figs. 6 and 7), and it probably represents the older part of the Subboreal Phase. The sequence above it includes three layers of mud (M-2, M-3 and M-4) separated by two layers of gravel (G-2 and G-3; Figs. 6 and 7). The mollusc assemblage identified within the muddy levels has a major proportion of shade-loving forms, but its species structure is very different from that described above (of layer M-1). There is a disappearance of species with high thermal requirements, and their place is taken by snails of greater ecological tolerance. The proportion of mesophilous forms also increases. These changes are the consequences of worsened climatic conditions. The effects included impoverishment of forest biocoenoses as well as the increased importance of coniferous trees, particularly Abies and Picea (Obidowicz, 1990; Rybniček and Rybničková, 2002), and, in some places, replacement of these by scrub vegetation. The emergence of such plant communities significantly decreased the diversity of the mollusc assemblages. Such a tendency is characteristic of the deposits associated with the Subboreal Phase. It is marked in many mollusc-bearing profiles within the Carpathians (Alexandrowicz, 1997b, 2001, 2004, 2014, 2017; Alexandrowicz et al., 2014, 2016; Juřičková et al., 2014b; Horáčková et al., 2015). This age interpretation is supported by the results of radiocarbon dating of plant remains from layer M-2 as follows: $4400 \pm 80$ years BP (3339-3206 cal $\mathrm{BC}$ and $3196-2897$ cal BC; C-9 and $3850 \pm 60$ years BP (2472-2189 cal BC and 2182-2141 cal BC; C-1), from layer M-3: $3350 \pm 40$ years BP (1741-1711 cal BC and 1700-1529 cal BC; C-7), and from layer M-4: $2930 \pm 50$ years BP (1279-993 cal BC and 987-980 cal BC; C-2), and $2780 \pm 50$ years BP (1049-820 cal BC; C-5; Figs. 6, 7 and Table 2). In the top part of the terrace, two layers of gravel can be distinguished (G-4 and G-5) separated by the youngest layer of muds (M-5) and covered by contemporary soil (Figs. 6 and 7). The first of these levels of gravel (G-4) is relatively thick at up to $0.4 \mathrm{~m}$, but it appears only in the lower part of the valley (Figs. 6 and 7). The higher level (G-5) extends along the whole length of the terrace studied, but it is thin (Figs. 6 and 7). The layer of mud separating the gravel beds decribed above is characterized by particularly high amounts of plant remains (layer M-5). Fragments of charcoal are also found there, and, at the top, there are sporadically occurring ceramic fragments. Relatively numerous molluscs also occur there. Their composition and structure are entirely different from the assemblages present in layers $\mathrm{M}-1-\mathrm{M}-4$; the most characteristic feature is the disappearance of shade-loving species. The predominant ecological group is that of the snails of open grassland habitats, accompanied by markedly fewer mesophilous forms (Figs. 6 and 7). Such a significant remodelling of the mollusc assemblage structure was associated with a rapid disappearance of forest communities. The dating of the basal part of this layer $(510 \pm 40$ years BP; 1318-1352 cal AD and 1390-1450 cal AD; C-3 and $480 \pm 40$ years BP; $1327-1343$ cal AD and 1394-1476 cal AD; C-10; Figs. 6, 7 and Table 2) indicate that initiation of mud deposition was in the second part of the 14th century. This period was associated with a phase of intense settlement activities. The influx of human groups into the Podhale region as well as to neighbouring lands resulted, inter alia, in extensive deforestation and the replacing of the original forest communities by grasslands and, in some areas, by cultivated fields. These processes are well-documented in palynological profiles of Podhale peatbogs (NAP phase; Obidowicz, 1990), as well as at many mollusc-bearing locations (Alexandrowicz, 1997b, 2004, 2013d). Similar phenomena are seen in large areas of the Carpathians (Alexandrowicz, 2004, 2013d; Horsák et al., 2007; Alexandrowicz et al., 2014, 2016). The basal layer of the gravels is associated with a period of intensified fluvial activity occurring in the most recent 100-200 years. The age determinations performed in the top part of layer M-5 gave the following results: $150 \pm 40$ years BP: $1666-1785$ cal AD, $1795-1893$ cal AD and $1907-\ldots$ cal AD; C-8 and $120 \pm 30$ years BP; $1679-1765$ cal AD and 1800-1940 cal AD; C-4 (Figs. 6, 7 and Table 2), supporting this interpretation.

As follows from the observations presented above, the evolution of the Falsztyński valley in the Late Holocene proceeded in stages. Periods of intensified fluvial activity, recorded in the form of gravel levels, were interspersed with phases typified by quieter sedimentation. In the latter periods, chiefly fine-grained sediments containing the remains of plants and snails were deposited. The mollusc assemblages described above indicate that, near the end of the Atlantic Phase and during the Subboreal Phase as well as during the older part of the Subatlantic Phase, the Falsztyński valley was overgrown by compact forests. Initially, these were mixed communities with a major proportion of deciduous trees. Later, with the worsening of climatic conditions, coniferous forests with Abies and Picea as their main components, as well as shrub vegetation, assumed increasingly important roles. A sudden change in the nature of habitats is marked in the younger part of the Subatlantic Phase, and it is associated with the development of settlement activities, extensive deforestation, and the subsequent emergence of open grassland biotopes. Similar environmental tendencies within the Podhale region and neighbouring lands are documented in palynological (Obidowicz, 1990; Rybniček and Rybničková, 2002) and mollusc-bearing profiles (Horsák et al., 2007; Alexandrowicz, 2013d; Alexandrowicz et al., 2014, 2016).

\section{CHRONOLOGY OF FLOOD PHASES}

The presence of gravel levels within the Falsztyński terrace can be linked to the periods of intensified fluvial activity of the stream. Studies conducted for many years in the Carpathian valleys (e.g., Starkel et al., 2006, 2015; Gębica, $2011,2013 a, b)$ suggest that these phases close relate to climate fluctuations, particularly corresponding to periods of increased humidity. Detailed studies of the internal structure of the Falsztyński terrace, of the palaeoenvironmental characteristics based on enclosed mollusc remains, and radiocarbon dates, help establish the age and duration of flood phases and to link these data with the results of studies carried out in other areas of the Carpathians (Fig. 8).

The oldest gravel layer (G-1) rests directly on bedrock except in Profile Fp-VI, where it is underlain by the oldest mud layer (M-1) dated at $5610 \pm 130$ years BP (4784-4229 cal BC 


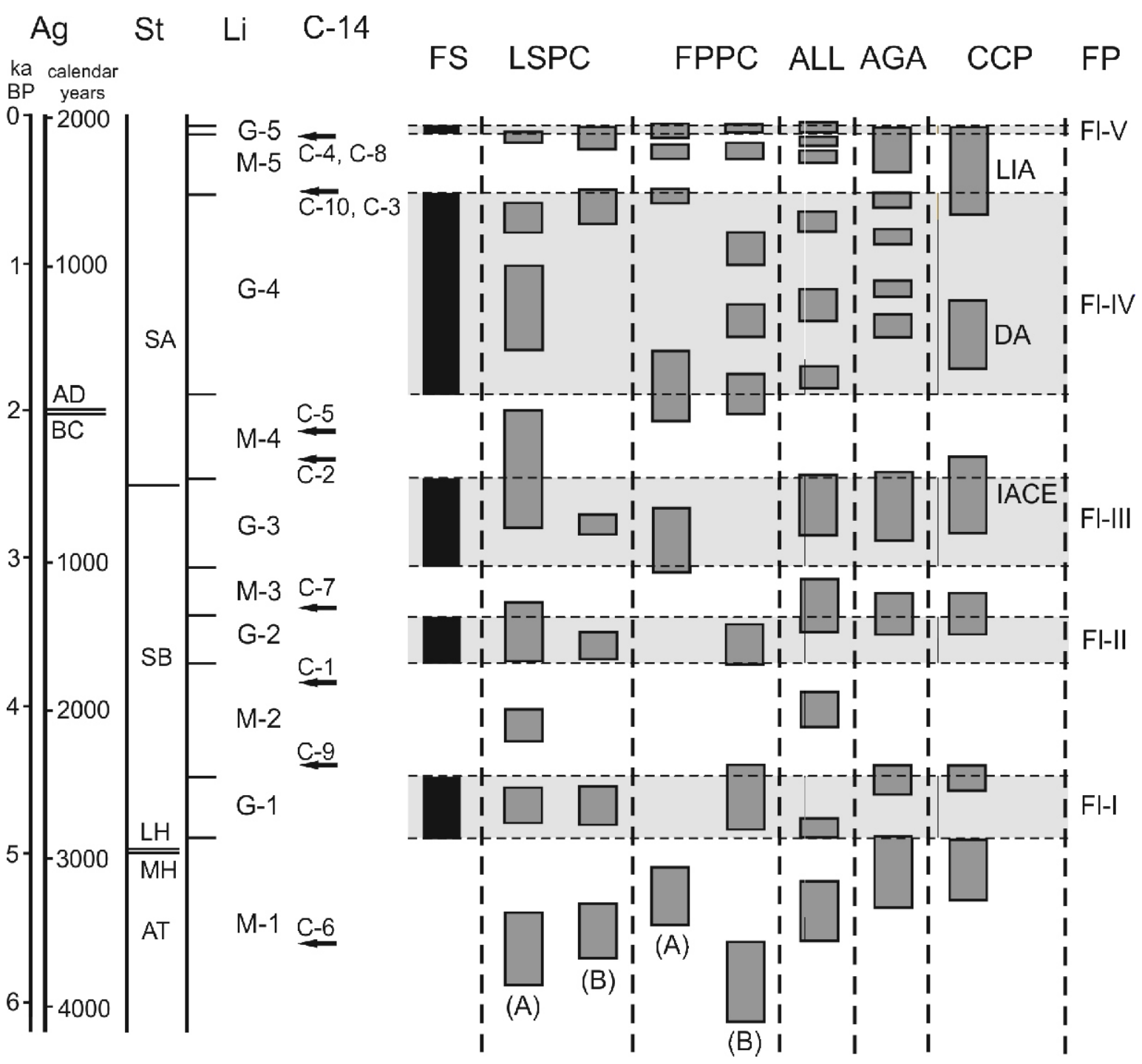

Fig. 8. Correlation model of climatic changes in central Europe during the Late Holocene

Ag - age; St - stratigraphy: At - Atlantic Phase, MH - Middle Holocene, LH - Late Holocene, SB - Subboreal Phase, SA Subatlantic Phase; $\mathrm{Li}$ - general lithology of alluvial deposits of the Falsztyński valley: G-1-G-5 - gravel units, M-1-M-5 mud units (described in text); C-14 - radiocarbon dates (C-1-C-10); FP - flood phases (FI-I-FI-V) described in the Falsztyński valley; FS - Falsztyński valley (this paper); LSPC - landslides in the Polish Carpathians [after Margielewski, 2006 (A); Alexandrowicz, 1996, 2013b (B)]; FPPC - flood phases in Polish Carpathians [after Starkel et al., 2006, 2015 (A); Gębica, 2011, 2013a, b (B)], ALL - phases of high water level in Alpine lakes (after Magny, 1993, 2004; Holzhauser et al., 2005); AGA - Alpine glacier advances (after Patzelt, 1977; Bortenschlager, 1982; Nussbaumer et al., 2011); CCP - cold climatic phases: IACE - Iron Age Cold Epoch, DA - Dark Ages Cold Epoch, LIA - Little Ice Age (after Grove, 1988; Briffa, 2000; Bradley, 2000; Mayewski et al., 2004)

and $4197-4173$ cal BC; C-6). The age determinations of the base of the mud layer covering this gravel (layer M-2) yielded the following ages: $4400 \pm 80$ years BP (3339-3206 cal BC and 3196-2897 cal BC; C-9; Figs. 6-8 and Table 2). The time frames so established allow linking of this phase to the period of increased climate humidity at the boundary between the Atlantic and Subboreal phases and/or the oldest part of the Subboreal Phase (Fig. 8). The humidification and cooling of the climate in that period brought about, apart from increased flow in the Carpathian rivers (e.g., Starkel et al., 2006, 2015; Gębica, $2011,2013 a, b)$, an increased intensity and frequency of mass movements (Alexandrowicz, 1997a, 2013b; Starkel, 1997;
Margielewski, 1998, 2006; Dapples et al., 2002). The same climatic phase is also marked in other parts of Europe. This is reflected in an increase in water levels in lakes both in European lowlands and the Alpine region (Ralska-Jasiewiczowa and Starkel, 1988; Magny, 1993, 2004; Wojciechowski, 1999; Holzhauser et al., 2005; Alexandrowicz, 2013a) as well as by the advance of glaciers in the Alps and Scandinavia (e.g., Patzelt, 1977; Bortenschlager, 1982; Karlén, 1988; Nesje, 2009; Nussbaumer et al., 2011; Fig. 8). The age range of the second layer of gravel (G-2) is constrained by radiocarbon dates within two muddy intercalations, which limit it, as indicated by the following: M-2 (3850 \pm 60 years BP, $2472-2189$ cal 
BC and 2182-2141 cal BC; C-1), as well as M-3 (3350 \pm 40 years BP, 1741-1711 cal BC and 1700-1529 cal BC; C-7; Figs. 6-8 and Table 2); the dates link these gravels with the middle part of the Subboreal Phase. Intensification of Carpathian fluvial activity took place at this time (e.g., Starkel et al., 2006, 2015; Geebica, 2011, 2013a, b), while the increased humidity also likely caused a number of landslides within the Carpathians (Starkel, 1997; Margielewski, 1998, 2006; Alexandrowicz, 1997a, 2013b). Advance of Alpine and Scandinavian glaciers (e.g., Patzelt, 1977; Bortenschlager, 1982; Karlén, 1988; Nesje, 2009; Nussbaumer et al., 2011) and an increase in water levels are also associated with this climatic phase (Ralska-Jasiewiczowa and Starkel, 1988; Wojciechowski, 1999; Magny, 1993, 2004; Holzhauser et al., 2005; Alexandrowicz, 2013a). The third gravel level (G-3) corresponds to the boundary between the Subboreal and Subatlantic phases, and it is constrained by the following dates: C-7 (layer M-3) - $3350 \pm 40$ years BP (1741-1711 cal BC and $1700-1529$ cal BC) and C-2 (layer M-4) $-2930 \pm 50$ years BP (1279-993 cal BC and 987-980 cal BC; Figs. 6-8 and Table 2). That period corresponds to the phase of cooler and more humid climate (Birks, 1990; Mackay et al., 2003; Mayewski et al., 2004) associated with an evident decrease in solar activity (van Geel et al., 1999). As a consequence, gravel accumulated in the Carpathian river valleys. Due to the presence of tree trunks within the deposits, this period is also well-documented via dendrochronological analyses (Krąpiec, 1996, 2001; Gębica and Krapiec, 2009). The humidification of climate observed at the boundary between the Subboreal and Subatlantic phases is also indicated by the intensification of mass movements (Alexandrowicz, 1997a, 2013b; Starkel, 1997; Margielewski, 1998, 2006), river activity (e.g., Starkel et al., 2006, 2015; Gębica, 2011, 2013a, b), an increase in lake levels (RalskaJasiewiczowa and Starkel, 1988; Wojciechowski, 1999; Magny, 1993, 2004; Holzhauser et al., 2005; Alexandrowicz, 2013a), as well as glacial advances in the Alps and on the Scandinavian Peninsula (Patzelt, 1977; Bortenschlager, 1982; Karlén, 1988; Nesje, 2009; Nussbaumer et al., 2011). The phase is termed the Iron Age Cold Epoch (Birks, 1990; Mackay et al., 2003; Mayewski et al., 2004). The next, fourth gravel level (G-4), is thick, but appears only in the lower part of the valley (Fig. 8). The age determinations $(2780 \pm 50$ years BP $(1049-820$ cal BC; layer M-4, date $C-5)$ and $510 \pm 40$ years $B P$; $1318-1352$ cal $A D$ and $1390-1450$ cal $A D$ and $480 \pm 40$ years BP; $1327-1343$ cal $A D$ and 1394-1476 cal AD (layer M-5, dates C-3 and C-10)) point to the younger part of the Subatlantic Phase. That period is probably associated with several climatic fluctuations of which the most prominent corresponds to the early Dark Ages Cold Period; (Birks, 1990; Mackay et al., 2003; Mayewski et al., 2004; Helama et al., 2017). In the Carpathian valleys, several flood phases are recorded (e.g., Starkel et al., 2006, 2015; Gębica, 2011, 2013a, b) that are separated by periods of slower sedimentation. These brief cool periods are also reflected in advances of the Alpine glaciers as well as in the periods of high lake levels (Patzelt, 1977; Bortenschlager, 1982; Ralska-Jasiewiczowa and Starkel, 1988; Magny, 1993, 2004; Wojciechowski, 1999; Holzhauser et al., 2005; Nussbaumer et al., 2011; Alexandrowicz, 2013a). In the Falsztyński valley, it is impossible to distinguish these minor climatic fluctuations. There is only one gravel layer, of remarkable thickness but with a homogeneous internal structure. The top of the low Falsztyński terrace is composed of the youngest gravel unit (G-5). It extends along the whole valley, but is thin (Fig. 8). It represents the most recent 200 years. The radiocarbon dates made of the top of the youngest mud unit (layer M-5) gave the following results: $150 \pm 40$ years BP: $1666-1785$ cal AD, $1795-1893$ cal AD and $1907-\ldots$ cal AD C-8 and $120 \pm 30$ years BP; $1679-1765$ cal AD and 1800-1940 cal AD; C-4 (Figs. 6-8 and Table 2). These results indicate that the G-5 layer formed during the cold and humid climate of the Little Ice Age. Within the most recent 200 years, there were two marked cooling periods that correlated with phases of decreased solar activity: the Maunder and Dalton minima (Lamb, 1977; Grove, 1988; Briffa, 2000; Bradley, 2000; Mayewski et al., 2004; Matthews and Briffa, 2005). The major intensification of floods in this period led to gravel accumulation, and also to the erosive deepening of river beds and cutting through older alluvial covers, widely described in the Carpathian river valleys (e.g., Starkel et al., 2006, 2015; Gębica, $2011,2013 a, b)$. This was also followed by the activation of landslides (Alexandrowicz, 1997a, 2013b; Starkel 1997; Margielewski, 1998, 2006). The Little Ice Age is also associated with involving Alpine glacier advance (Patzelt, 1977; Bortenschlager, 1982; Nussbaumer et al., 2011) and a rise in lake level (Ralska-Jasiewiczowa and Starkel, 1988; Wojciechowski, 1999; Magny, 1993, 2004; Holzhauser et al., 2005; Alexandrowicz, 2013a). In the Falsztyński valley, this period is associated with the accumulation of the youngest gravels as well as with the latest erosion of the terrace down to bedrock (Fig. 8).

\section{CONCLUSIONS}

Studies of the low terrace deposits of the Falsztyński valley have reconstruction of environmental changes on the basis of mollusc assemblage analysis, constraining the chronology of phases of increased fluvial activity in the Late Holocene. Analysis of rich mollusc material preserved in mud layers (layers $M-1-M-5)$, showed a general persistence of shaded habitat. These were compact, initially mixed forests; however, with worsening conditions for vegetation during the Subboreal Phase, they showed an increasing proportion of coniferous trees, chiefly Abies and Picea. Such changes in vegetation brought about a gradual decrease in mollusc species diversity, particularly the disappearance of taxa with higher ecological requirements. Faunal assemblages associated with the Atlantic and Subatlantic phases are described from a number of locations in the Podhale region, but those corresponding to the Subboreal Phase are known only to a small extent. In this respect, the Falsztyński river profiles are exceptional. Rapid change in habitat took place in the Middle Ages. This correlates with the warm period of the Medieval Climatic Optimum (Grove and Switsur, 1994; Bradley, 2000; Briffa, 2000; Jones and Mann, 2004), when large human groups appeared in the Podhale area (Ralska-Jasiewiczowa and Starkel, 1988; Czepiel, 1999). The need for cultivated fields and pastures led to extended deforestation, mainly in areas of low relief and wide river valleys (Alexandrowicz, 1997b, 2013d). The Falsztyński valley was among such deforested areas. The record of these processes is easily readable in mollusc-bearing profiles, reflected by the disappearance of rich assemblages dominated by shade-loving species and their replacement by species-poor assemblages composed chiefly of taxa typical of open habitats.

The Late Holocene included characteristic climate fluctuations. During the humid periods, intensified fluvial activity took place over large areas of Europe, with enhanced gravel accumulation. Within the Falsztyński terrace, five levels of gravels can be distinguished (G-1-G-5), their chronology constrained by radiocarbon dating. Particular phases encompass the end of the Atlantic Phase and the oldest part of the Subboreal Phase $(\mathrm{F}-1)$, the middle part of the Subboreal Phase (F-2), as well as the boundary interval between the Subboreal and Subatlantic phases (F-3), the younger part of the Subatlantic Phase (F-4), 
and the most recent 200 years (F-5). The chronology of these phases correlates well with similar schemes worked out in studies of rivers, landslides, glaciers and lakes in other Carpathian and Alpine zones, with local variations resulting from individual valley characteristics and the morphological and climatic conditions across the whole Podhale Basin.
Acknowledgments. This study has been sponsored by the AGH University of Science and Technology through University grant no 11.11.140.005. I also would like to thank Prof. $P$. Sümegi and an anonymous reviewer for their constructive comments.

\section{REFERENCES}

Alexandrowicz, S.W., 1997a. Holocene dated landslides in the Polish Carpathians. Palaeoclimate Research, 19: 75-83.

Alexandrowicz, W.P., 1997b. Malacofauna of Quaternary deposits and environmental changes of the Podhale Basin during the Late Glacial and Holocene (in Polish with English summary) Folia Quaternaria, 68: 7-132.

Alexandrowicz, W.P., 2001. Late Vistulian and Holocene molluscan assemblages from calcareous tufa at Ostrysz Hill (Podhale Basin). Folia Malacologica, 9: 159-169.

Alexandrowicz, W.P., 2004. Molluscan assemblages of Late Glacial and Holocene calcareous tufa in Southern Poland. Folia Quaternaria, 75: 3-309.

Alexandrowicz, W.P., 2013a. Late Glacial and Holocene molluscan assemblages in deposits filling palaeolakes in Northern Poland. Studia Quaternaria 30: 5-17.

Alexandrowicz, W.P., 2013b. Molluscan assemblages in the deposits of landslide dammed lakes as indicators of late Holocene mass movements in the Polish Carpathians. Geomorphology, 180-181: 10-23.

Alexandrowicz, W.P., 2013c. Malacological sequence from profile of calcareous tufa in Groń (Podhale Basin, southern Poland) as an indicator of the Late Glacial/Holocene boundary. Quaternary International, 293: 196-206.

Alexandrowicz, W.P., 2013d. Molluscan communities in Late Holocene fluvial deposits as an indicator of human activity: a study in Podhale Basin in Southern Poland. Ekologia Bratislava, 32 $111-125$.

Alexandrowicz, W.P., 2015. The application of malacological analysis in the study of slope deposits: Late Pleistocene and Holocene of the Podhale Basin (Carpathians, Poland). Acta Geologica Polonica, 65: 245-261.

Alexandrowicz, W.P., 2017. Malacofauna of the Holocene tufa in the Valley of the Ociemny Stream (Pieniny Mts., southern Poland). Geology, Geophysics and Environment, 43: 5-18.

Alexandrowicz, S.W., Alexandrowicz, W.P., 2011. Analiza malakologiczna - metody badań i interpretacji (in Polish). Rozprawy Wydziału Przyrodniczego PAU, 3: 5-302.

Alexandrowicz, W.P., Rybska, E., 2013. Environmental changes of intermontane bains derived from malacological analysis of profile of calcareous tufa in Niedzica (Podhale Basin, Southern Poland). Carpathian Journal of Earth and Environmental Sciences, 8: 13-26.

Alexandrowicz, W.P., Szymanek, M., Rybska, E., 2014. Changes to the environment of intramontane basins in the light of malacological research of calcareous tufa: Podhale Basin (Carpathians, Southern Poland). Quaternary International, 353 : 250-265.

Alexandrowicz, W.P., Szymanek, M., Rybska, E., 2016. Molluscan assemblages from Holocene calcareous tufa and their significance for palaeoenvironmental reconstructions. A study in the Pieniny Mountains (Carpathians, southern Poland). Carpathian Journal of Earth and Environmental Sciences, 11: 37-54.

Birkenmajer, K., 1977. Jurassic and Cretaceous lithostratigraphic units of the Pieniny Klippen Belt. Studia Geologica Polonica, 45: $1-158$

Birkenmajer, K., 1986a. Stages of structural evolution of the Pieniny Klippen Belt, Carpathians. Studia Geologica Polonica, 88: 7-32.
Birkenmajer, K., 1986b. Falsztyn. Przewodnik do 57 zjazdu PTG, Pieniny 18-20.09.1986: 107-113.

Birks, H.J.B., 1990. Changes in vegetation and climate during the Holocene of Europe. In: Landscape-Ecological Impact of Climatic Change (eds. M.M. Boer and R.S. de Groot): 133-158. IOS Press, Amsterdam.

Bortenschlager, S., 1982. Chronostratigraphic subdivision of the Holocene in the Alps. Striae, 16: 75-79.

Bradley, K.R., 2000. Past global changes and their significance for the future. Quaternary Science Reviews, 19: 391-402.

Briffa, K.R., 2000. Annual climate variability in the Holocene: interpreting the message of ancient trees. Quaternary Science Reviews, 19: 87-105.

Bronk Ramsey, C., 2017. Methods for summarizing radiocarbon dates. Radiocarbon, 59: 1809-1833.

Czepiel, J., 1999. Z dziejów osadnictwa na Podhalu (in Polish). Abrys, Kraków.

Dapples, F., Lotter, A.F., van Leeuven, J.F.N., van der Knapp, W.O., Dimitriadis, S., Oswald, D., 2002. Palaeolimnological evidence for increased landslide activity due to forest clearing and land-use since 3600 cal BP in the western Swiss Alps. Journal of Paleolimnology, 27: 239-248.

Gębica, P., 2011. Stratigraphy of alluvial fills and phases of the Holocene floods in the lower Wisłok river. Geographia Polonica, Special Issue I: 39-60.

Gębica, P., 2013a. Chronostratigraphy of alluvia and age of fluvia landforms in the Carpathians foreland during the Vistulian. Studia Quaternaria, 30: 19-27.

Gębica, P., 2013b. Geomorphological records of human activity reflected in fluvial sediments in the Carpathians and their foreland. Landform Analysis, 22: 21-31.

Gębica, P., Krąpiec, M., 2009. Young Holocene alluvia and dendrochronology of subfossil trunks in the San river valley. Studia Geomorphologica Carpatho-Balcanica, 43: 63-75.

Golonka, J., Krobicki, M., Waśkowska, A., 2018. The Pieniny Klippen Belt in Poland. Geology, Geophysics and Environment, 44: 111-125.

Grove, J., 1988. The Little Ice Age. London-New York, Methuen.

Grove, J.M., Switsur, R., 1994. Glacial geological evidence for the Medieval Warm Period. Climatic Change, 26: 143-169.

Helama, S., Jones, P.D., Briffa, K.R., 2017. Dark Ages Cold Period: a literature review and directions for future research. The Holocene, 27: 1600-1606.

Hammer, Ø., Harper, D.A.T., Ryan, P.D., 2001. Past: paleontological statistics software package for education and data analysis. Palaeontologica Electronica, 4: 1-9.

Holzhauser, H., Magny, M., Zumbuühl, H.J., 2005. Glacier and lake-level variations in west-central Europe over the last 3500 years. The Holocene, 15: 789-801.

Horáčková, J., Ložek, V., Juřičková, L., 2015. List of malacologically treated Holocene sites with brief review of palaeomalacological research in Czech and Slovak Republics. Quaternary International, 357: 207-211.

Horsák, M., Hájek, M., Dítě, D., Tichy, L., 2007. Modern distribution patterns of snails and plants in the western Carpathian spring fens: is it a result of historical development? Journal of Molluscan Studies, 73: 53-60. 
Horsák, M., Juřičkova, L., Picka, J., 2013. Molluscs of the Czech and Slovak Republics. Nakladatelstvi Kabourek, Zlin.

Jones, P.D., Mann, M.E., 2004. Climate over past millennia. Reviews of Geophysics, 42: 1-42.

Juřičkova, L., Horsák, M., Horáčková, J., Ložek, V., 2014a. Ecological groups of snails - use and perspectives. European Malacological Congress, Cambrige, UK, poster. (www. http://mollusca.sav.sk/malacology/Jurickova/2014-ecological-groups-poster.pdf)

Juřičková, L., Horáčková, J., Ložek, V., 2014b. Direct evidence of Central European forest refugia during the Last Glacial Period based on mollusc fossils. Quaternary Research, 82: 222-228.

Karlén, E., 1988. Scandinavian glacial climatic fluctuation during the Holocene. Quaternary Science Reviews, 7: 199-209.

Kerney, M.P., Cameron, R.A.D., Jungbluth, J.H., 1983. Die Landschnecken Nord- und Mitteleuropas. Verlag P. Parey, Hamburg-Berlin.

Krąpiec, M., 1996. Dendrochronology of black oaks from river valleys in Southern Poland. Geographical Studies, part VI, Special Issue, 9: 61-78.

Krąpiec, M., 2001. Holocene dendrochronological standards for subfossil oaks from the area of Southern Poland. Studia Quaternaria, 18: 47-63

Krolopp, E., Sumegi, P., 1993. Vertigo modesta (Say 1924), Vertigo geyeri Lindholm 1925 and Vertigo genesii (Gredler 1856) species in Pleistocene formations of Hungary. Malacological Newsletter, 12: 9-14.

Lamb, H.H., 1977. Climate: present, past and future 2, climatic history and the future. Methuen, London.

Limondin-Lozouet, N., 1992. Biogeographie Holocene de Vertiginidae (Mollusca - Gastropoda) Europeens: relations la derniere deglaciation. Compest Rendus de l'Académie des Sciences Paris, 315: 1281-1287.

Ložek, V., 1964. Quartärmollusken der Tschechoslowakei. Rozpravy Ustředniho Ustavu Geologického, 31: 1-374.

Mackay, A., Battarbee, R., Birks, J., Oldfield F., eds., 2003. Global Change in the Holocene. Edward Arnold, London.

Magny, M., 1993. Holocene fluctuation of lake levels in the French Jura and Sub-Alpine ranges, and their impactions for past general circulation patterns. The Holocene, 3: 306-313.

Magny, M., 2004. Holocene climatic variability as reflected by mid-European lake-level fluctuations, and its probable impact on prehistoric human settlements. Quaternary International, 113: $65-79$.

Margielewski, W., 1998. Landslide phases in the Polish Outer Carpathians and their relation to the climatic changes in the Late Glacial and Holocene. Quaternary Studies in Poland, 15: 37-53.

Margielewski, W., 2006. Record of the Late Glacial-Holocene climatic changes in landslide forms and deposits of the Beskid Makowski and Beskid Wyspowy Mts. area (Polish Outer Carpathians). Folia Quaternaria, 76: 1-149.

Matthews, J.A., Briffa, K.R., 2005. The 'Little Ice Age': re-evaluation of an evolving concept. Geografiska Annaler, 87 A: 17-36.

Mayewski, P.A., Rohling, E.E., Stager, J.C., Karlen, W., Maasch, K.A., Meeker, L.D., Meyerson, E.A., Gasse, F., van Kreveld, S., Holmgren, K., Lee-Thorp, J., Rosqvist, G., Rack, F., Staubwasser, M., Schneider, R.R., Steig, E.J., 2004. Holocene climate variability. Quaternary Research, 62: 243-255.
Morisita, M., 1959. Measuring of interspecific association and similarity between communities. Memoris of the Faculty of Sciences, Kyushu University, E, 3: 65-80.

Nesje, A., 2009. Latest Pleistocene and Holocene alpine glacier fluctuations in Scandinavia. Quaternary Science Reviews, 28: 2119-2136.

Nussbaumer, S.U., Steinhilber, F., Trachsel, M., Breitenmoser, P., Beer, J., Blass, A., Grosjean, M., Hafner, A., Holzhauser, H., Wanner, H., Zumbühl, H.J., 2011. Alpine climate during the Holocene: a comparison between records of glaciers, lake sediments and solar activity. Journal of Quaternary Science, 26: 703-713.

Obidowicz, A., 1990. Eine pollenanalytische und moorkundlische Studie zur Vegetationgeschichte des Podhale-Gebietes (West-Karpaten). Acta Palaeobotanica, 30: 147-219.

Patzelt, G., 1977. Der zeitliche Ablauf und Ausmass postglazialer Klimaschwankungen in den Alpen. Veröffentlichungen Museum Ferdinandeum, 67: 93-123.

Pokryszko, B.M., 1990. The Vertiginidae of Poland (Gastropoda: Pulmonata: Pupillidae) - a systematic monograph. Annales Zoologici, 43: 133-257.

Pokryszko, B.M., 2003. Vertigo of continental Europe - autecology, threats and conservation status (Gastropoda, Pulmonata, Vertiginidae). Heldia, 5: 13-26.

Ralska-Jasiewiczowa, M., Starkel, L., 1988. Record of the hydrological changes during the Holocene in the lake, mire and fluvial deposits of Poland. Folia Quaternaria, 57: 91-127.

Rybniček, K., Rybničková, E., 2002. Vegetation of the Upper Orava region (NW Slovakia) in the last 11000 years. Acta Palaeobothanica, 42: 153-170.

Schenková, V., Horsák, M., Plesková, Z., Pawlikowski, P., 2012. Habitat preferences and conservation of Vertigo geyeri (Gastropoda: Pulmonata) in Slovakia and Poland. Journal of Molluscan Studies, 78: 105-111.

Starkel, L., 1997. Mass movement during the Holocene: Carpathian example and the European perspective. Palaeoclimate Research, 19: 385-400.

Starkel, L., Soja, R., Michczyńska, D.J., 2006. Past hydrological events reflected in Holocene history of Polish rivers. Catena, 66: 24-33.

Starkel, L., Michczyńska, D.J., Gębica, P., Kiss, T., Panin, A. Perşoiu, I., 2015. Climatic fluctuations reflected in the evolution of fluvial systems of Central-Eastern Europe (60-8 ka cal BP). Quaternary International, 338: 97-118.

Van Geel, B., Raspopov, O.M., Renssen, H., van der Plicht, J., Dergachev, V.A., Meijer, H.A.J., 1999. The role of solar forcing upon climate change. Quaternary Science Reviews, 18: 331-138.

Welter-Schultes, F.W., 2012. European non-marine molluscs, guide for species identification. Planet Poster Editions, Göttingen.

Wiktor, A., 2004. Ślimaki lądowe Polski (in Polish). Wydawnictwo Mantis, Olsztyn.

Wojciechowski, A., 1999. Late Glacial and Holocene lake-level fluctuations in the Kórnik-Zaniemyśl lakes area, Great Poland Lowland. Quaternary Studies in Poland, 16: 81-101. 